\title{
The visualizer and verbalizer cognitive style as critical thinking in geometrical problem solving
}

\author{
Widodo Winarso, Widya Yulistiana Dewi \\ Department of Mathematics Education Faculty of Tarbiyah and Teacher Science \\ IAIN Syekh Nurjati Cirebn, Indonesia
}

\begin{abstract}
Student's strategy in solving mathematics problem cannot be separated from the way students receive and process the information obtained which is called as cognitive style. Students have different cognitive styles as they learn. There are students who tend to have a cognitive style of visualizer and there are also students who tend to have a cognitive style of verbalizer. The different cognitive styles will trigger students' critical thinking skills. This research was conducted in Junior High School (Madrasah Tsanawiyah Daru'l Hikam Kota Cirebon) by using the quantitative method of a causal-comparative type. The sampling technique used cluster random sampling, with a total sample of 45 students, 24 students visualizer, and 21 students verbalizer. The results showed that the visualizer students obtained an average score of 50.15, while the verbalizer students obtained a smaller average score of 40.05 . When viewed from the average percentage of the results of each aspect of critical thinking, visualizer students can be categorized quite well, while the verbalizer students can be categorized less. Research Results Show that there are differences in critical thinking between students with cognitive style visualizer and students with cognitive style of verbalizer in solving geometry problems.
\end{abstract}

Keywords: Critical thinking, cognitive style, geometry problems-solving

\section{Introduction}

Mathematics learning is a process of providing learning experiences about mathematics to learners through planned activities prepared by educators. In learning mathematics, educators must provide opportunities for students to try and find their own experience related to the math objects that are being studied. According to Burton (2012), the purpose of learning mathematics is to encourage students to become problem solvers based on critical, logical, and rational thinking processes. However, most students consider that learning mathematics is a difficult learning because most students lack a high interest when encountering difficult mathematical problems and even tend to avoid them.

Student's strategy in solving the problem especially on the material of geometry, of course, can not be separated from the way students receive and process the information obtained which is called as cognitive style. Students have different styles in solving problems and when they learn. Students will choose the preferred way of processing and organize information in response to their environment (Sari \& Budiarto, 2016).

According to Uno (2006), that cognitive style is a different way to see, recognize, and organize information. However, most educators are less aware of the type of cognitive style of each student. Therefore, a teacher is required to be able to know the type of cognitive style of his students. According to Keefe (1979), cognitive style grouping is based on four dimensions: (1) Perceptual modality preference; is a cognitive style that is related to the habits and preferences of a person in using his sensory apparatus. Especially visual or spatial viewing ability, auditory or verbal understanding, (2) Field-dependent field 
independent; is a cognitive style that someone has in interacting with the environment, (3) Scanning; is a description of a person's tendency to focus his attention on an information, and (4) Strong and weakness automatization; is a picture of one's capacity to display tasks (task) repeatedly.

The information presented in mathematics can be a verbal symbol and a visual symbol. Acceptance of information in the form of verbal symbols and visual symbols is included in the perceptual modality preference, the information can be accepted by students may differ depending on the cognitive style. According to McEwan \& Reynolds (2007), cognitive styles related to a person's habits using his senses are divided into two groups, the visualizer, and the verbalizer. A person with a cognitive style visualizer tends to be easier to receive, process, store, and use information in the form of images and graphics (Hegarty \& Kozhevnikov, 1999). While a person with a cognitive style verbalizer tends to be easier to receive, process, store, and use information in the form of text or written writing.

The same thing is also expressed by Klein (3003), that students with cognitive visualizer style, have a tendency to receive information in visual learning (eg, diagrams, drawings, and graphs). While the likes like oral information that can be read or heard included into the student's cognitive style verbalizer.

This cognitive style difference certainly affects the strategy used in solving math problems. So students with different cognitive styles, of course, problem-solving strategies are different so that differences will trigger differences in students' critical thinking skills (Sari \& Budiarto, 2016).

The ability to think is basic in a learning process (Heong, Yunos, Hassan, Othman, \& Kiong, 2011). Critical thinking allows students to analyze their thoughts in making choices and draw conclusions intelligently. The ability to think critically is part of high-order thinking (Krulik, 1996). When children are given the opportunity to use higher-level thinking at every grade level, they are eventually used to distinguishing between truth and lies, appearance and reality, facts and opinions, knowledge and constancy. The ability to think critically is a reflective and reasoned way of thinking focused on decision-making to solve problems (Ennis, 1985). Thus, this mental process will generate the critical thinking ability of students to be able to master math in depth.

In the empirical order, based on literature studies conducted found that the results of research Jacob (2012) explains that learning mathematics in critical thinking skills, when properly encouraged can produce improvements in mathematical achievement. Meanwhile, according to Kim, Sharma, Land \& Furlong (2013) that through the application of the active learning module, the average student's critical level falls in the "developing" category, but the student's score on individual reports shows a statistically significant increase. Valindra (2014) disposition and inference skills have shown significant contributions to critical mathematical thinking abilities.

While Based on interviews with mathematics subject teachers in one of Junior High School (Madrasah Tsanawiyah Daru'l Hikam), students' critical thinking skills in learning mathematics are still lacking, as seen from some students when given a little different exercise from the sample problem already explained the students feel difficulty. As the case study conducted by the researcher in the class, that students have difficulty in working on geometry problems related to everyday life, in this case, the students still lack thinking in more depth. In addition, students are also less precise in answering questions. Students only memorize the formula alone without understanding it, so students do not set the strategy in answering questions. 
Of these two things, the critical thinking skills of students need to be developed for success in learning mathematics, especially on solving geometry problems.

Critical thinking can assist students in improving the understanding of the material learned by critically evaluating the arguments on the books, group discussions, tasks in solving problems, and also including teacher arguments in learning activities. A teacher needs to think through appropriate steps to create a mathematical learning process that provides an opportunity for students to develop their critical thinking skills.

Teachers can practice critical thinking skills by exposing students to challenging issues, such as geometry. These challenging issues will provide opportunities To students to use all the abilities they possess including high-order thinking that is critical thinking. Bailin, Case, Coombs, \& Daniels (1999) define competence in critical thinking having the required intellectual resources to accomplish certain tasks adequately and along with the habit of applying them appropriately.

Description of the stage of critical thinking can be seen through the steps of students in solving geometry problems. The steps in answering student problems vary between the cognitive-style visualizer with cognitive-style verbalizer. So in need of a teacher's ability to understand the image of students' critical thinking. Such treatment is necessary so that the teacher can see the suitability of making the learning design with the cognitive style of the students.

Based on the above description, then the formulation of problems in this study, including; 1) How to distribute cognitive style of students, 2) how critical thinking skills of students in review of the cognitive style of visualizer and verbalizer in solving geometry problems, and 3) Are their differences of students' critical thinking between cognitive-style visualizer students with cognitive-style verbalizer students in solving problems geometry.

\section{Method}

The research method used in this research is a quantitative method of causalcomparative type (Mertens, 2014). The focus of this research is about students' critical thinking in terms of cognitive style of visualizer and verbalizer in solving geometry problems. This research was conducted in Junior High School (Madrasah Tsanawiyah Daru'1 Hikam Kota Cirebon).

The sampling technique used in this study was Cluster Random Sampling, the researchers took a random sample of groups, in which case the group was regarded as a learning group. Researchers used a lottery method to determine the sample (Kothari, 2004). While to get the target of research sample, researcher gives questionnaire to all students of class VIII B and VIII C from class VIII that exist. This is done to identify the cognitive style of students categorized into the verbalizer or visualizer. Then got the sample in this research is class VIII B which consists of 14 student visualizer and 11 student verbalizer, while for class VIII C consist of 10 student visualizer and 10 student verbalizer.

The data collection instruments used in this study were questionnaires and tests (Cohen, Manion \& Morrison, 2013). The questionnaire used in this study was developed by the author. As in the process of its developers adopted from the concept of cognitive style (Thomas \& McKay, 2010) and attitude scale measurement (Boone \& Boone, 2012). Questionnaire or questionnaire is a closed questionnaire, used to classify the cognitive style of each student. The questionnaire consisted of 24 statement items divided into 2 sections ie 12 statements for the cognitive style of the visualizer and 12 statements for the cognitive 
style of the verbalizer. Each statement has 4 alternative answers that are, Strongly Agree (SS), Agree (S), Disagree (TS), Strongly Disagree (STS) with Likert scale.

Likewise with the test instruments, the test used in the form of Essays developed by researchers. The development of the test adopted from the concept of achievement of learning geometry in high school (Van de Walle, Karp \& Williams, 2007) and development of essay tests (Ennis, \& Weir, 1985; Detlefsen, 2013). The number of essay tests used as many as 8 items. Where the essay test is used to measure students' critical thinking skills.

The hypothesis in this study is a comparational hypothesis. Hypothesis test used in this research is t-test (Independent Samples T-Test). But before doing hypothesis testing, then in need of testing a prerequisite that includes the test of normality and homogeneity test.

If the student's critical thinking data is normally distributed then the test is continued with homogeneity test and hypothesis test that is t-test for two independent samples. Conversely, if the critical thinking data obtained students are not normally distributed then the test is continued with homogeneity test and hypothesis test that is test Mann Whitney U.

\section{Results and Discussion}

The results of the study after the field study, based on the cognitive style questionnaire in class VIII B Madrasah Tsanawiyah Daru'l Hikam Kota Cirebon, students tend to have cognitive style visualizer as much as $56 \%$ (14 people) and students tend to have verbalizer cognitive style as much as $44 \% 11$ people). This suggests that most students in grade VIII B tend to have a cognitive style of the visualizer. Meanwhile, based on the results of cognitive style questionnaire distribution in class VIII C Madrasah Tsanawiyah Daru'l Hikam Kota Cirebon, students tend to have visualizer cognitive style as much as $50 \%$ (10 people) and students tend to have cognitive style verbalizer as much as $50 \%$ (10 people). This shows that the number of students in class VIII C who have the cognitive style of visualizer as much as students who have cognitive style, verbalizer.

The distribution of cognitive style shows the level of diversity of students' cognitive style. This is used as a predictor in this study. because, cognitive style is recognized as an important psychological dimension as a distinguishing individual way of obtaining and processing information (Ausburn \& Ausburn, 1978). in addition, that cognitive styles have been recognized differently from cognitive abilities, intelligence, personality, and learning styles (Kozhevnikov, 2007; Riding, 1997). The cognitive style is also a predictor of good academic performance when compared to studies of individual intelligence (Sternberg \& Zhang, 2014).

This will affect the students' thinking ability in solving math problems. Solving mathematical problems, especially in geometry materials can be done by thinking simple and critical thinking. According to Ennis (1985), critical thinking is a reflective and sensible thought that focuses on determining what to do or believe. The ability to think critically includes such things as applying available information to new situations, analyzing the causes or motives for the situation, and evaluating opinions about a particular subject. While Mcpeck (2016) defines critical thinking as a skill and disposition to appropriately use reflective skepticism. Lipman claims that critical thinking is a feasible thought to judge, based on criteria, correcting, and critically content (Lipman, 2003).

The diversity of cognitive styles is the focus of discussion related to the critical thinking of students in solving geometry problems. The research data related to the achievement of critical thinking of students is as follows. 
Table 1, Descriptive Statistics Results

\begin{tabular}{|c|c|c|c|c|c|c|}
\hline & $\mathrm{N}$ & Minimum & Maximum & Mean & $\begin{array}{c}\text { Std. } \\
\text { Deviation }\end{array}$ & Variance \\
\hline $\begin{array}{l}\text { Critical Thinking of } \\
\text { Verbalizer Students }\end{array}$ & & 35 & 73 & 50,15 & 11,595 & 134,445 \\
\hline Valid N (listwise) & 24 & & & & & \\
\hline $\begin{array}{l}\text { Critical Thinking of } \\
\text { Verbalizer Students }\end{array}$ & 21 & 22 & 63 & 40,05 & 13,577 & 184,323 \\
\hline Valid N (listwise) & 21 & & & & & \\
\hline
\end{tabular}

Based on the results of the statistical descriptive analysis, the average value of students' critical thinking with the cognitive style of visualizer in solving the geometry problem is 50.15 . While students with cognitive style verbalizer obtained the average value of students' critical thinking in solving geometry problems is 40.05 . This means that students with cognitive style visualizer tend to be better than students with cognitive style verbalizer in solving geometry problems.

This difference in cognitive style of students has an effect on critical thinking skills. Critical thinking involves logical reasoning and the ability to separate fact from opinion, separating information critically with proof before it is received or rejected.

In other words that critical thinking keeps students to analyze, question issues, give ideas, provide solutions to problems solved. So that students can make intelligent decisions when facing challenges in learning (Rfaner, 2006). Meanwhile, according to Fahim \& Pezeshki (2012), that the ability to think critically involves reasoning and active consideration of what is received from the acceptance of ideas just like that. Other opinions reflect critical thinking as reflective thinking that can be adapted to the concept of thinking, such as higher-order thinking, problem-solving, and metacognition (Ennis 1987, 1989, McPeck, 1990).

Mathematics learning should involve students 'involvement in active learning techniques, in the context of interpersonal skills can improve students' critical thinking (Burbach, Matkin \& Fritz, 2004). So in need of cooperative learning that can build these critical thinking skills.

In the same context, based on student data on critical thinking tests in solving geometry problems, it is known that students with cognitive visualizer styles excel in three aspects, namely providing simple explanations, building basic skills, and organizing strategies and tactics. While students with verbalizer cognitive style excel at two aspects of critical thinking in solving the problem of geometry, the aspects of concluding and providing further explanation. As can be seen in the following chart: 


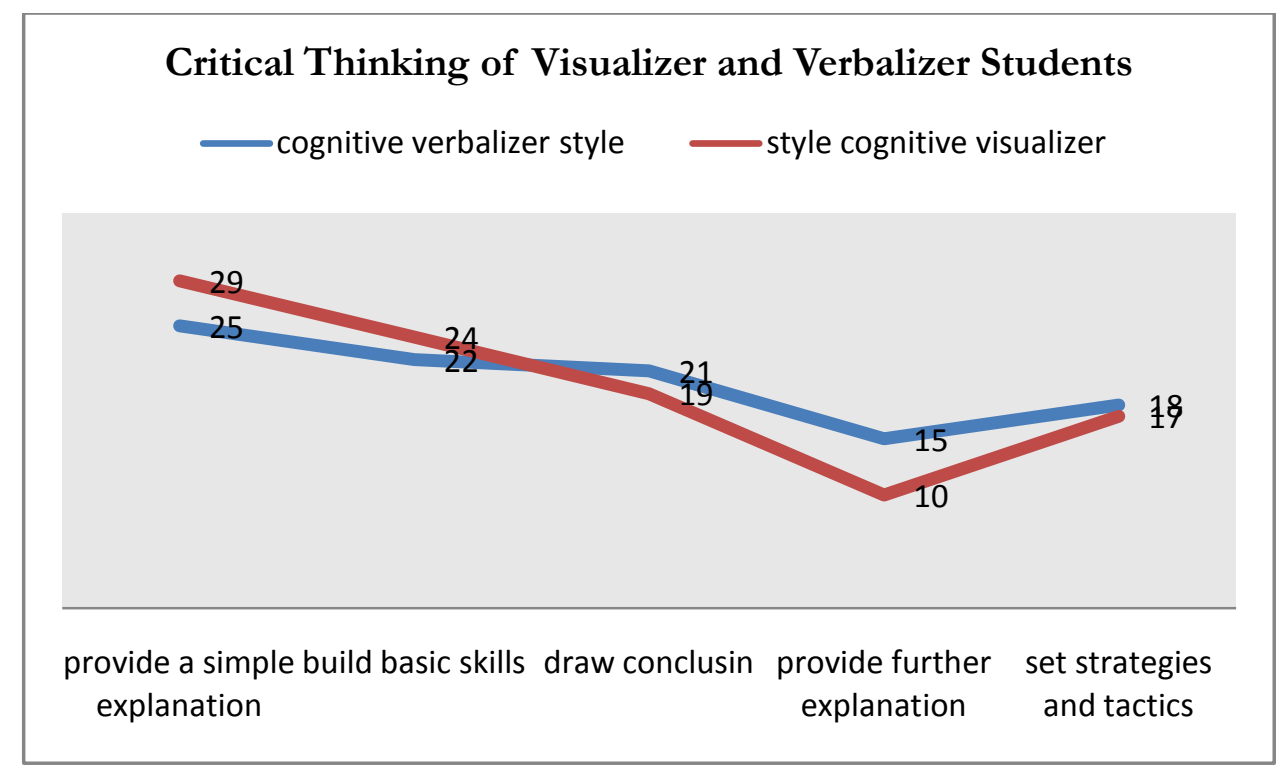

Chart 1. Comparison of Student's Critical Thinking

In the first aspect, the aspect of "the ability to provide simple explanations" is superior to cognitive visualizer-style students when compared to cognitive-style verbalizer students. With the magnitude of the percentage is $4 \%$. In the second aspect, the "build basic skills" aspect is superior to cognitive visualizer-style students when compared to students of cognitive verbalizer styles. With the magnitude of the percentage is $2 \%$. This means students with cognitive style visualizer able to provide answers with a simple explanation (short) but clear in solving geometry problems, and able to build basic skills of geometry.

While in the third and fourth aspects have the meaning of other trends. Students of cognitive verbalizer style, when compared with visualizer style students, in verbalizer cognitive style students superior to the conclusion ability with the magnitude of the percentage, is $2 \%$, and the ability to provide further explanation related to the problem of geometry with the difference of the percentage is $5 \%$. Another case on the fifth aspect, namely the aspect of "the ability to set strategies and tactics". Students of cognitive visualizer style are superior to $1 \%$ achievement when compared with students of cognitive verbalizer style.

The next analysis is hypothesis testing. But before the testing is done, then the requirements of hypothesis test requirements. it is used to determine whether the data analysis can be continued or not.

First, the normality test, this prerequisite data analysis is used to find out whether the population of data obtained through the critical thinking test of students in solving geometry problems normally distributed or not. Testing using Shapiro-Wilk. The requirements of the hypothesis test (normality test) are as follows.

Table 2. Tests of Normality

\begin{tabular}{lcrrrrr}
\hline & \multicolumn{3}{c}{ Kolmogorov-Smirnova } & \multicolumn{4}{c}{ Shapiro-Wilk } \\
\cline { 2 - 7 } & Statistic & df & Sig. & Statistic & df & Sig. \\
\hline $\begin{array}{l}\text { Critical } \\
\text { thinking }\end{array}$ & \multirow{2}{*}{068} & 45 & \multirow{2}{*}{, $200^{*}$} &, 978 & 45 & \multirow{2}{*}{, $\mathbf{5 2 6}$} \\
\hline *. This is a lower bound of the true significance. & & \\
a. Lilliefors Significance Correction & & & &
\end{tabular}

Based on table 2, it is known that from the data combined between the students with cognitive visualizer and verbalizer style obtained significance value (sig.) In the Shapiro- 
Wilk column of 0.526. Since the significance value (sig.) Generated in the Shapiro-Wilk column is greater than the value of a selected, ie $\alpha=0.05$, then the data is declared normal. Thus, it can be concluded that at $95 \%$ confidence level, critical thinking data of students with the cognitive style of visualizer and verbalizer in solving the problem of normally distributed geometry.

Both homogeneity tests, this prerequisite data analysis is used to find out whether the population of data obtained through the critical thinking test of students in solving the geometry problem has the same variant of data population or not.

Table 3. Test of Homogeneity of Variances

\begin{tabular}{rrrr}
\hline $\begin{array}{c}\text { Critical thinking } \\
\text { Levene Statistic }\end{array}$ & df1 & df2 & Sig. \\
\hline 1,944 & 1 & 43 & $\mathbf{, 1 7 0}$ \\
\hline
\end{tabular}

Based on table 3, it is known that the value of P-value shown in the significance column (sig.) Is 0.170 . The value is greater than the value of a selected, ie $a=0.05$. Since the value of P-value> $\mathrm{a}$, then $\mathrm{H} 0$ is accepted. Thus, it can be concluded that at the level of confidence $95 \%$ variance data critical thinking students with cognitive style visualizer and verbalizer in solving the problem of geometry is homogeneous distribution.

After performing the prerequisite test, hypothesis testing is performed. Where hypothesis testing using Independent Sample T-Test. obtained the results of research data as follows.

Table 4. Independent Samples T Test Results

\begin{tabular}{llll}
\hline & & \multicolumn{2}{c}{\begin{tabular}{c} 
Critical thinking \\
\cline { 3 - 4 }
\end{tabular}} \\
& & $\begin{array}{l}\text { Equal } \\
\text { variances } \\
\text { assumed }\end{array}$ & $\begin{array}{l}\text { Equal } \\
\text { variances not } \\
\text { assumed }\end{array}$ \\
\hline $\begin{array}{l}\text { Levene's Test } \\
\text { for Equality of }\end{array}$ & $\mathrm{F}$ & 1,944 & \\
Variances & Sig. &, 170 & \\
& $\mathrm{~T}$ & 2,692 & 2,663 \\
t-test for & Df & 43 & 39,636 \\
Equality of & Sig. (2-tailed) &, 010 &, 011 \\
Means & Mean Difference & 10,098 & 10,098 \\
& Std. Error Difference & 3,752 & 3,792 \\
& 95\% Confidence & Lower 2,532 & 2,432 \\
& Interval of the & Upper 17,664 & 17,764 \\
\hline
\end{tabular}

Based on the above table, by doing two kinds of testing obtained as follows; first, Levene's Test for Equality of Variances test is to test the homogeneous data or not. While the second, T-test forEquality of the Means test is to test whether the data have an average difference or not.

In the Levene's Test results for Equality of Variances, we get the P-value indicated by the Sig line. on the assumed equal variances column of 0.170 so that the second variance of the data is homogeneous because the value is greater than $(\alpha=0,05)$. In the T-test for Equality of Means test, the value residing in column $t$ is t_hitung obtained from the calculation. In the equal variances assumed column, the $t$ value indicates the student on the critical thinking test in solving the geometry problem, which is 2,692. In the $\mathrm{df}$ line, the value 
43 is assigned, the value represents the degree of freedom in the test performed. On the Sig line. (2-tailed) value of P-value (significance) in the test of critical thinking of students in solving geometry problem equal to 0,010. The Mean Difference row shows the difference in mean scores between cognitive-style visualizer students and cognitive-style verbalizer students in solving geometrical problems.

It is known before that the average value of critical thinking of students with visualizer cognitive style in solving geometry problem is 50.15 and the mean value of critical thinking of students with the cognitive style of verbalizer in solving geometry problem is 40,05 so that the average difference of 10,098. Tests of T-test for Equality of Means hypothesis using $95 \%$ confidence level so that a used is 0.05 . To find the value of $t$ tabel with $a=0,05$ and $d k=43$ use Microsoft Excel help $(=\operatorname{TINV}(0,05 ; 43))$ so that the value of $t_{\text {tabel }}=2,016$ or $-2,016$.

Thus, the values obtained $t_{\text {count }}>t_{\text {table }}=2.692>2.016$, and the value of Sig. (2-tailed) $<\alpha=0,010<0,05$. So his decision H0 rejected. This means at $95 \%$ confidence level can be concluded that there is a difference in the problem-solving ability of geometry between students with cognitive-style visualizer with cognitive verbalizer-style students.

Results Differences in the ability of problem-solving geometry can be described as follows;

First, Students with Cognitive style visualizers can mention several important things in distinguishing relevant and irrelevant sections of a given problem (Kozhevnikov, Kosslyn \& Shephard, 2005). However, there is still inaccuracy for the subject of the visualizer in translating information in tests of solving and writing information that it knows. The subject of the visualizer in collecting information tends to classify information with certain criteria. Furthermore, the subject of the visualizer is more interested in solving the problem with the picture. These conditions, in line with Mendelson (2004) who said that the subject of the visualizer interested in information in the form of images. Based on the explanations that have been presented, the subject visualizer understands the problem by distinguishing relevant and irrelevant information. While Mendelson \& Thorson (2004) showed that the subject of visualizers in generalizing the problem tends to use the initial letter symbol of the word object on a given problem.

Second, the cognitive verbalizer student mentions all important things in distinguishing relevant and irrelevant parts of a given problem. The subject of a verbalizer in collecting information tends to sort in the order in which it is known. Furthermore, the subject of verbalizer is more interested in solving the problems that many use the words. Such conditions, in line with Mendelson's (2004) opinion that the subject of the verbalizer is interested in information in the form of words. Reinforced view according to Mendelson \& Thorson (2004) which states that the subject of verbalizer in generalizing the problem with the use of symbols that tend to be consistent.

\section{Conclusion}

Based on the results of analysis and research on the comparative study of students' critical thinking in terms of cognitive style of visualizer and verbalizer in solving geometry problems, it can be concluded that:

1. Spreading cognitive style in class VIII B Madrasah Tsanawiyah Daru'l Hikam Kota Cirebon tend to have the cognitive style of the visualizer. Meanwhile, the distribution of cognitive style in class VIII C as much between visualizer and verbalizer. 
2. Students with cognitive style visualizer get the average value of critical thinking test in solving the geometry problem of 50.15. Based on the average acquisition percentage of results from each aspect of critical thinking students with visualizer cognitive style can be categorized quite well.

3. Students with verbalizer cognitive style obtain an average value of critical thinking test in solving geometry problems of 40.05 . Based on the average acquisition percentage of results from each aspect of critical thinking students with cognitive style verbalizer can be categorized less well.

4. There is a difference between the mean value of critical thinking ability of a student with the cognitive style of visualizer and student with cognitive verbalizer style in solving a geometry problem.

Suggestion from this researcher is student should more practice about geometry to accustomed in solving geometry problem with the technique of settling that variation so that student can improve critical thinking ability. Mathematics teachers, should convey materials or provide training should not always be fixated with the book so that students' critical thinking skills are more trained, and teachers should know the type of cognitive style that is owned by students in order to support the learning process of mathematics. The next researcher should consider broader material in order to dig deeper into the students' critical thinking skills in solving geometrical problems.

\section{References}

Ausburn, L. J., \& Ausburn, F. B. (1978). Cognitive styles: Some information and implications for instructional design. Educational Technology Research and Development, 26(4), 337-354.

Bailin, S., Case, R., Coombs, J. R., \& Daniels, L. B. (1999). Conceptualizing critical thinking. Journal of curriculum studies, 31(3), 285-302.

Baxter, P., \& Jack, S. (2008). Qualitative case study methodology: Study design and implementation for novice researchers. The qualitative report, 13(4), 544-559.

Boone, H. N., \& Boone, D. A. (2012). Analyzing likert data. Journal of extension, 50(2), 1-5.

Burbach, M. E., Matkin, G. S., \& Fritz, S. M. (2004). Teaching critical thinking in an introductory leadership course utilizing active learning strategies: A confirmatory study. College Student Journal, 38(3), 482.

Burton, L. (Ed.). (2012). Learning mathematics: From hierarchies to networks. Routledge.

Cohen, L., Manion, L., \& Morrison, K. (2013). Research methods in education.Routledge.

DePorter, B., Reardon, M., \& Singer-Nourie, S. (2010). Quantum teaching: mempraktikkan quantum learning di ruang-ruang kelas. Kaifa.

Detlefsen, M. (2013). Hilbert's program: an essay on mathematical instrumentalism (Vol. 182). Springer Science \& Business Media.

Ennis, R. (1987). A taxonomy of critical thinking dispositions and abilities. Teaching thinking skills: Theory and practice, 9-26.

Ennis, R. H. (1985). Goals for a critical thinking curriculum. Developing minds: A resource book for teaching thinking. Alexandria, VA: Association for Supervision and Curriculum Development, 68-72.

Ennis, R. H. (1989). Critical thinking and subject specificity: Clarification and needed research. Educational researcher, 18(3), 4-10.

Ennis, R. H., \& Weir, E. E. (1985). The Ennis-Weir critical thinking essay test: An instrument for teaching and testing. Midwest Publications.

Fahim, M., \& Pezeshki, M. (2012). Manipulating critical thinking skills in test taking. International Journal of Education, 4(1), 153.

Hegarty, M., \& Kozhevnikov, M. (1999). Types of visual-spatial representations and mathematical problem solving. Journal of educational psychology, 91(4), 684.

Heong, Y. M., Yunos, J. M., Hassan, R. B., Othman, W. B., \& Kiong, T. T. (2011). The perception of the level of higher order thinking skills among technical education students. In International 
Conference on Social Science and Humanity journal. Faculty of Technical Education, Universiti Tun Hussein Onn Malaysia (Vol. 5, No. 2, pp. 281-285).

Jacob, S. M. (2012). Mathematical achievement and critical thinking skills in asynchronous discussion forums. Procedia-Social and Behavioral Sciences, 31, 800-804.

Keefe, J. W. (1979). Learning style: An overview. Student learning styles: Diagnosing and prescribing programs, 1, 1-17.

Kendall, P. C., \& Hollon, S. D. (Eds.). (2013). Cognitive-behavioral interventions: Theory, research, and procedures (Vol. 21). Academic Press.

Kim, K., Sharma, P., Land, S. M., \& Furlong, K. P. (2013). Effects of active learning on enhancing student critical thinking in an undergraduate general science course. Innovative Higher Education, 38(3), 223-235.

Klein, P. D. (2003). Rethinking the multiplicity of cognitive resources and curricular representations: Alternatives to'learning styles' and'multiple intelligences'. Journal of curriculum studies, 35(1), 45-81.

Kothari, C. R. (2004). Research methodology: Methods and techniques. New Age International.

Kozhevnikov, M. (2007). Cognitive styles in the context of modern psychology: toward an integrated framework of cognitive style. Psychological bulletin, 133(3), 464.

Kozhevnikov, M., Kosslyn, S., \& Shephard, J. (2005). Spatial versus object visualizers: A new characterization of visual cognitive style. Memory \& cognition, 33(4), 710-726.

Krulik, S. (1996). The new sourcebook for teaching reasoning and problem solving in junior and senior high school. Allyn \& Bacon.

Lipman, M. (2003). Thinking in education. New York: Cambridge University Press.

McEwan, R. C., \& Reynolds, S. (2007). Verbalisers and Visualisers: Cognitive Styles that are less than equal. Fanshawe College: Disability Services, Counselling \& Student Life.

McPeck, J. E. (1990). Critical thinking and subject specificity: A reply to Ennis. Educational Researcher, 19(4), 10-12.

McPeck, J. E. (2016). Critical thinking and education. New York : Routledge.

Mendelson, A. L. (2004). For whom is a picture worth a thousand words? Effects of the visualizing cognitive style and attention on processing of news photos. Journal of Visual Literacy, 24(1), 122.

Mendelson, A. L., \& Thorson, E. (2004). How verbalizers and visualizers process the newspaper environment. Journal of Communication, 54(3), 474-491.

Mertens, D. M. (2014). Research and evaluation in education and psychology: Integrating diversity with quantitative, qualitative, and mixed methods. Sage publications.

Rfaner, S. (2006). Enhancing thinking skills in the classroom. Humanity \& Social Sciences Journal, 1(1), 28-36.

Riding, R. J. (1997). On the nature of cognitive style. Educational psychology, 17(1-2), 29-49.

Sari, E. M. J., \& Budiarto, M. T. (2016). Profil Berpikir Kritis Siswa SMP dalam Menyelesaikan Masalah Geometri Ditinjau dari Gaya Kognitif Visualizer dan Verbalizer. Jurnal Ilmiah Pendidikan Matematika Volume, 2(5). 39-47.

Sternberg, R. J., \& Zhang, L. F. (Eds.). (2014). Perspectives on thinking, learning, and cognitive styles. Routledge.

Thomas, P. R., \& McKay, J. B. (2010). Cognitive styles and instructional design in university learning. Learning and Individual Differences, 20(3), 197-202.

Uno, H. B. 2006. Orientasi Baru dalam Psikologi Pembelajaran. Jakarta: Bumi Aksara.

Valindra, D. (2014). The Contribution Of Disposition And Inference Skills To Critical Thinking Mathematics Ability Of Students At Senior High School Jakarta. In: Ratu Ilma (Eds).The Second South East Asia Design/ Development Research (SEA-DR) International Conference, April 26-27,2014, Unsri, Palembang, April 26th-27th,2014, Palembang.

Van de Walle, J. A., Karp, K. S., \& Williams, J. M. B. (2007). Elementary and middle school mathematics. Teaching development. Boston: Pearson. 


\section{Author Information}

Widodo Winarso

IAIN Syekh Nurjati Cirebon-Indonesia

Department of Mathematics Education

Contact e-mail: widodoiain@gmai.com
Widya Yulistiana Dewi

IAIN Syekh Nurjati Cirebon-Indonesia

Department of Mathematics Education 